\title{
Perceptions of Policymakers in Nigeria Toward Unsafe Abortion and Maternal Mortality
}

\section{By Friday E. \\ Okonofua, Afolabi \\ Hammed, Emily \\ Nzeribe, Buba \\ Saidu, Tajudeen \\ Abass, Gabriel \\ Adeboye, Temi \\ Adegun and Chike \\ Okolocha}

Friday E. Okonofua

is executive director,

Women's Health and

Action Research

Centre, and professor

of obstetrics and gyne-

cology, University of

Benin, Benin City,

Nigeria. Afolabi

Hammed is research

associate, Women's

Health and Action

Research Centre. Emily

Nzeribe is consultant obstetrician and

gynecologist, Federal

Medical Centre,

Owerri, Nigeria;

Buba Saidu is director,

Borno State Ministry

of Health, Maiduguri,

Nigeria; Tajudeen

Abass is researcher, Ahmadu Bello

University Teaching Hospital, Zaria,

Nigeria; Gabriel

Adeboye is chief

medical director, Hope

Specialist Hospital,

Akure, Nigeria; and

Temi Adegun is chief

medical director,

General Hospital,

Ikere, Nigeria-all

of whom are also

research associates at

the Women's Health

and Action Research

Centre. Chike

Okolocha is professor

of sociology and an-

thropology, University of Benin.

CONTEXT: In Nigeria, abortion is permitted only to save the life of a woman. Unsafe abortion is common and is a major cause of maternal mortality, yet policymakers have done little to address the problem.

METHODS: In-depth interviews were conducted in 2008 with 49 Nigerian politicians and officials to assess their awareness of unsafe abortion and its role in maternal mortality, and to determine their perceptions of the policies and actions needed to address these problems.

RESULTS: Participants had poor knowledge of Nigeria's abortion law and the number of abortions and abortion-related deaths, though many knew of women who had died or nearly died from unsafe abortion. Policymakers were guided by moral and religious considerations rather than by evidence-based approaches. About one-third of informants felt that abortion should not be legal under any circumstances, one-fifth supported liberalization on medical grounds and a similar proportion believed that abortion should be legal in cases of rape and incest. Strategies recommended by respondents to reduce maternal mortality included facilitating access to contraceptives, providing sexuality education, improving the health care system, empowering women and providing free pregnancy care.

CONCLUSIONS: Intense public health education and advocacy targeting policymakers is needed to increase political will for reducing abortion-related maternal deaths in Nigeria. Presenting statistics on unsafe abortion together with compelling personal stories will likely resonate with policymakers and contribute to an informed public debate on abortion law reform.

International Perspectives on Sexual and Reproductive Health, 2009, 35(4):194-202

Nigeria has one of the most restrictive abortion laws in the world: Abortion is permitted only to save the life of a woman, and persons who violate the law are subject to lengthy jail terms-up to seven years for a woman obtaining an abortion for other reasons and 14 years for any provider convicted of performing an illegal procedure. ${ }^{1}$ As a result, many women with unwanted pregnancies seek clandestine, unsafe abortions. A 1998 study estimated that 760,000 induced abortions are performed in Nigeria each year, equivalent to an annual rate of 25 per 1,000 women aged $15-44,{ }^{2}$ and this may be an underestimate of the true incidence of the procedure. ${ }^{3}$

To date, the impact of unsafe abortion on the reproductive health of women in Nigeria has been poorly investigated, in part because of the paucity of data and the clandestine nature of most procedures. However, several reports indicate that unsafe abortion is a critical public health problem and a leading cause of maternal mortality in Nigeria. ${ }^{2-4}$ Data from the Federal Ministry of Health ${ }^{5}$ and other sources ${ }^{6,7}$ suggest that unsafe abortion accounts for $20-40 \%$ of maternal mortality in the country. Abortion has also been reported to be a leading cause of long-term reproductive morbidity-including chronic pelvic pain, ectopic pregnancy, infertility and recurrent pregnancy lossin Nigerian women. ${ }^{7-10}$

Despite the high rates of morbidity and mortality asso- ciated with unsafe abortion, the Nigerian government has taken very little action to address the problem. While Nigeria has national policies on reproductive health and safe motherhood, none explicitly address the problem of unsafe abortion. ${ }^{11-13}$ In addition, although contraceptive use can prevent unwanted pregnancy (and hence reduce the need for abortion), very few government-funded family planning programs have been established, despite the fact that the prevalence of modern contraceptive use among married women in Nigeria in 2003 was only $8 \%{ }^{14}$-one of the lowest rates in Sub-Saharan Africa. Government programs to provide postabortion care, which can reduce the burden of unsafe abortion, are also lacking. Most funding of family planning and postabortion care programs has been provided by donors, but many nongovernmental organizations have been reluctant to work on unsafe abortion for fear of losing U.S. funding because of the so-called global gag rule (though with the recent abrogation of this policy, the situation may improve).

Since the 1990s, several international conventions have urged stakeholders to take action on the problem of unsafe abortion in developing countries. ${ }^{15-18}$ Although Nigerian officials attended many of these conferences and signed the relevant resolutions, they have not addressed the issue. An attempt in 2007 to reform the country's restrictive abortion law was opposed by women's groups 
and a very active antiabortion lobby, and officials not only failed to explain the advantages of reform but failed to respond at all. ${ }^{19}$ More recently, two bills submitted to the national assembly-one designed to fully implement in Nigeria the terms of the international Convention for the Elimination of all Forms of Discrimination Against Women (which Nigeria signed in 1985) and the other to establish an Institute of Reproductive Health in the country-were withdrawn because antiabortion protesters accused the bills' sponsors of attempting to loosen restrictions on abortion.

Because it contributes to maternal mortality, unsafe abortion is an essential issue to address if Nigeria is to meet the Millennium Development Goal of reducing maternal mortality by $75 \%$ from its 1990 level by 2015. Official statistics indicate that maternal mortality increased in the 1990s, and it continues to increase, ${ }^{14}$ despite the 1987 launch of the international Safe Motherhood Initiative. For years, several nongovernmental organizations and professional associations have advocated reform of abortion policies in Nigeria. However, unless the government takes concrete steps to address the problem, there is little chance of success any time soon, as the lack of progress is largely due to inadequate support at the popular and policy levels.

In this study, we explored policymakers' knowledge of, attitudes toward and perceptions of unsafe abortion and maternal mortality, and their views regarding the need to reform the country's abortion law. We believe that the results will be useful in developing relevant policies and programs aimed at reducing morbidity and mortality associated with unsafe abortion in Nigeria.

\section{DATA AND METHODS}

We interviewed key policymakers responsible for making executive and legislative decisions on matters relating to maternal health in Nigeria. The country, which has a federal system of government and an estimated population of 140 million people, consists of 36 states, 774 local government councils and a Federal Capital Territory (Abuja). Administratively, it is divided into six geopolitical zones (north-west, north-east, north-central, south-west, southeast and south-south), each comprising six contiguous states that have similar social, cultural and religious profiles. The Federal Capital Territory functions as a distinct administrative unit.

We had planned to interview 55 policymakers, but five prospective participants could not be reached despite several attempts, and one declined to be interviewed. Of the 49 interviews we completed, 10 were conducted in the north-west zone, four in the north-east, five in the northcentral, seven in the south-east, 10 in the south-west, six in the south-south and seven in the Federal Capital Territory. Participants included health officials, women's affairs officials and members of the national and state legislative assemblies.

In each zone, a team comprising a medical practitioner with expertise in reproductive health, a sociologist or social worker and a local contact person was constituted to organize the interviews. Before conducting interviews, each team leader (who could be any of the three team members) and co-interviewers attended a two-day training workshop in Abuja to learn the study's objectives and methods and to improve their capacity to conduct interviews. During the workshop, the study protocol was finalized; the key informants to be interviewed were identified from among known women's health advocates; a uniform method for meeting and interviewing the informants was developed and adopted; the interview guide was pretested; and use of the guide and audio-recording equipment was demonstrated. The workshop was supervised by two social scientists versed in qualitative research methods, as well as a representative from the Guttmacher Institute, who provided training on qualitative data analysis.

Following the workshop, participants returned to their zones to contact the key informants and conduct the interviews. The interview guide, which consisted of openended, value-free questions, is presented in the appendix (page 202). The interviewers first explored the respondents' knowledge of the high rate of maternal mortality in Nigeria and the factors responsible for maternal deaths, as well as their perceptions of the relationship between unsafe abortion and maternal mortality. Next, respondents were asked about the reasons that women resort to abortion, specific ways to reduce unsafe abortion in Nigeria, and the roles of sexuality education and contraception in reducing the rate of unsafe abortion. Respondents were also asked about their knowledge and perceptions of Nigeria's abortion law, and whether they believed any changes need to be made. The final questions concerned what should be done to reduce abortion-related maternal mortality, and maternal mortality in general, in Nigeria.

Prospective participants were informed of the purpose of the study, and only those who consented to participate and to be audio-recorded were interviewed. Participants were told that their responses would be kept confidential, and they were assured that their names would not appear in the study report. Ethical approval for the study was obtained from the Ethical Review Committee of the University of Benin Teaching Hospital.

All interviews were conducted in 2008; they lasted a minimum of 45 minutes and were conducted in English by a team consisting of the interviewer, a note-taker and an assistant who operated the audio recorder. Interview transcripts were coded by question topics, and respondents' spontaneous and prompted comments were analyzed for content concerning subthemes and questions posed during the interviews. Data analysis was performed using N6 qualitative software (QSR International).

\section{RESULTS}

\section{Causes of Maternal Mortality}

All key informants acknowledged that many women die in Nigeria each year as a result of pregnancy complications. Although some attempted to illustrate the severity of the 
problem by citing figures, only two correctly reported the current national maternal mortality statistics. Bleeding during childbirth (obstetrical hemorrhage) was the complication most commonly cited by the informants as a medical cause of maternal mortality; other complications, in decreasing order of frequency of reporting, were malaria in pregnancy, pre-eclampsia/eclampsia, abortion, ruptured uterus, obstructed labor, anemia and AIDS.

Informants also cited a variety of social factors that contribute to maternal deaths in Nigeria. For example, they noted that pregnant women often fail to recognize symptoms of severe disease during pregnancy and use inappropriate treatments rather than evidence-based approaches. The high level of poverty in the country adds to the problem, as pregnant women may not seek antenatal and delivery care in health institutions because they are unable to pay for services. In addition, respondents reported that maternal mortality is associated with several traditional practices, including early marriage and female genital mutilation.

Other social factors included cultural beliefs and practices that disempower women-in particular, those that severely restrict women's ability to obtain antenatal, delivery and postnatal care. A government health official explained:

"Culturally, women in Pudha [a practice wherein a woman covers her body so that it is not exposed to men other than her husband] are not allowed to go to the hospital during pregnancy; their spouses go to the hospital on their behalf, since [women] are not allowed to see male doctors."

Another top health official noted a different dimension of cultural restrictions on women:

"In the rural areas, for a woman to ask for assistance when she is in labor is a sign of weakness."

Certain religious beliefs were also listed as factors contributing to maternal mortality. Some respondents reported that women often base their decisions regarding whether to seek care on religious injunctions and dogma. The policymakers did not appear to challenge the validity of these beliefs, in part because of their own conviction about the importance and relevance of religion. The following statements from policymakers illustrate the scope of the problem:

"In northern Nigeria, religious leaders educate women that it is against Islamic doctrine to seek medical help from a male doctor. In addition, they still believe that the process of childbearing is God-given and that it is the duty of God to complete the process, and therefore no one should interfere with delivery."-Government health official

"Some religions forbid blood transfusion. [I had] a patient who was a Jehovah's Witness; she refused to be transfused although she was bleeding profusely. Even her relatives refused to allow her to be transfused, and at the end of the day she died. Some women believe that if you are sick, the right place to seek care is a religious center rather than a hospital."-Medical doctor and policymaker

Other factors mentioned by multiple informants as con- tributing to maternal mortality in Nigeria included lack of a functional health care system, concentration of health facilities in urban areas, delays in women getting to hospitals for emergency care, lack of medical facilities and poor attitudes on the part of health care providers.

\section{Abortion as a Cause of Maternal Mortality}

When asked about the extent to which abortion is a factor in maternal mortality in Nigeria, most respondents (39) reported that abortion contributes to a "large" degree. Several felt that abortion plays a smaller role, while five reported that they did not know.

Particularly noteworthy was the large number of informants who described their own experiences with women who had died or nearly died from complications of unsafe abortion. Respondents spoke of deep personal and societal losses and gave vivid accounts of feeling shame and helplessness at not being able to avert the deaths. Some examples follow:

"The question reminds me of the death of my sister, who died as a result of complications of unsafe abortion. I know what it cost me to lose a younger one; I watched her die and I could do nothing."-Legislator

"I once [knew] a woman [whose] husband [had wanted] a boy, and this was the seventh pregnancy. She discovered that it was a girl, and so they decided to procure an abortion, but the woman almost lost her life in the process. Although they succeeded in [ending the pregnancy], the woman's life was in jeopardy, which could have resulted in her death."-Government health official

"I have seen a lot of cases, most times the ones done by quacks. I have seen a case where the uterus was perforated and the gut was pulled out through the vagina. By the time the patient got to us, there was severe septicemia and the patient eventually died."-Government health official

"Yes, I know of a woman who went to procure an abortion. She didn't die, but she lost her womb in the process. Right now she doesn't have a womb and she can never deliver a child again."-Government health official

When asked why they thought women resorted to unsafe abortion in Nigeria, the vast majority of informants (42) reported that women sought abortions when they had unwanted pregnancies. The inability to take care of a child (or an additional child) because of poverty was the most common reason mentioned for a pregnancy being unwanted. The nonuse of contraceptives, in part due to lack of knowledge of available methods, was an additional factor mentioned by respondents; they noted that religious beliefs, social influences, stigmatization and the fear of shame often prevented women from using contraceptives to prevent an unwanted pregnancy. Paradoxically, when such pregnancies occur, women often forget religious injunctions and resort to unsafe abortion, again to avoid social stigma. Not only is a pregnancy outside wedlock frowned upon in many communities, respondents reported, but adolescents attending school often leave or are expelled if they become pregnant, resulting in the curtail- 
ment of their education and career prospects. In other cases, the desire to continue their education and to prevent societal rebuke often drives unmarried women to resort to abortion when they experience unwanted pregnancies:

"Last year, two students [had abortions] in secret, the clinic is unknown. One died. ... In most cases, they go to the quack clinics, and after injecting them, [the staff] sends them home immediately. These children will come back home bleeding, and they may not even reveal the truth to their parents until the worst is done."-Legislator

In addition to lack of awareness about contraceptives and religious belief, the most-cited reasons that women do not practice family planning included misconceptions about the benefits and side effects of contraceptives, the perception that contraceptives encourage promiscuity in women, lack of spousal consent and lack of women's empowerment. A top government health official cited several of these factors:

"Some religions frown at contraceptive usage. Another aspect is the lack of permission from the spouse; the husband will think if he allows his wife [to use contraceptives], she will be promiscuous. Some women even think [contraceptive use] can cause infertility; some think it can destroy vital parts of their bodies. Some feel it is something the Europeans did for their selfish interests to reduce our population. Fear of side effects, that it might cause cancer, is another issue."

Peer influences and inadequate parental communication were mentioned by some respondents as factors contributing to unwanted pregnancy and unsafe abortion among adolescents. In addition, most respondents acknowledged that rape and incest could result in unwanted pregnancies and unsafe abortion; they generally attributed sexual violence to poor parenting and lack of education about reproductive health, and some believed that these problems need to be tackled to reduce the number of rapes.

\section{The Nigerian Abortion Law}

Thirty-six of the 49 policymakers knew that abortion is illegal in Nigeria except to save the life of a woman. However, none of them could report the specific provisions of the law (e.g., the circumstances under which abortion can be legally performed). One respondent reported that abortion is illegal except on "medical grounds," while 12 said they were not conversant with the abortion law. Thus, poor knowledge of the law was widespread, which some policymakers attributed to the fact that the law is rarely enforced, and very few women or health professionals have ever been prosecuted.

Informants' attitudes toward the abortion law varied widely. More than one-third opined that abortion should not be legal under any circumstance, and a significant proportion suggested that the solution to unsafe abortion is not to legalize the procedure but to provide sexuality education. Religious and moral concerns were the most common reasons for opposing liberalization of abortion laws.
Examples of these views include the following:

"Abortion is morally wrong and illegal."-Government health official

"The causes of abortion should be addressed, rather than legalizing abortion."-State health official

"Liberalizing abortion is not an issue, but change of societal values is the most important thing."-Legislator

"Sexuality education ought to be advocated, instead of abortion legalization."-State health official

"I won't encourage liberalizing the abortion law, [nor] would I encourage abortion, because if a law exists...all necessary legal actions [should be taken] against those [who break it]. I believe [the law] will discourage and reduce the number of unwanted pregnancies and illicit sex."-Women's affairs official

Only four respondents felt that the abortion law in Nigeria is ineffective. In the view of a top state government health official, "Whether [the abortion law] is liberalized or not, people will procure abortion." Overall, one-fifth of respondents (10) favored a more flexible law that would increase access to safe abortion for women who had experienced contraceptive failure; a similar proportion favored a law that would allow abortion in cases of rape, incest and HIV/AIDS.

Some of the views that support liberalization and a more flexible abortion law included the following:

"There should be an alternative law."-National legislator

"Abortion should be practiced on medical grounds." -National legislator

"A new law should be put in place like that of Britain." -Government health official

"We should have government clinics where abortion will be free."-National legislator

Views also diverged on whether liberalizing the abortion law would affect the number of procedures performed-28 respondents thought that liberalization would increase the number of abortions, while 21 posited that liberalization would have no effect. Those who believed that liberalization would increase the number of abortions argued as follows:

"Of course it will increase it, and the young ones will go ahead living the rough life the way they want, saying once [an unwanted pregnancy occurs] they can do something about it. So it should not be liberalized."-Government health official

Another respondent suggested that while liberalization would affect the number of abortions that are performed, it would have an even greater impact on the number that are officially documented:

"It will increase the number of patients trying to procure [legal] abortion, [so] you will have an increased number of recorded cases. Unlike now, where criminal abortion is taking place on a daily basis but [the procedures] are not recorded."-Government health official

An official of the National Assembly offered an alternative view: 
"The fear of an increase is unfounded, as a holistic approach to the problem through promotion of reproductive health (as part of the liberalization process) will reduce the proportion of women who experience unwanted pregnancies."

Another top government health official argued that the importance of giving women the right to choose an abortion outweighs any concerns about the impact of legalization on the prevalence of the procedure:

"Although there are some concerns in the community that when you make the law liberal, people will procure abortion at will, as a provider [I think] there is a need to use the rights approach. It is important to make choices available and to guide individuals with the right information to make the correct choices on matters affecting their lives."

\section{Ways to Reduce Abortion and Related Mortality}

We asked respondents what could be done to reduce the number of abortions and the number of maternal deaths due to abortion. Although nonuse of contraceptives is a major risk factor for unwanted pregnancy and unsafe abortion, we asked about ways to increase the use of contraceptives only after we had asked about ways to prevent abortion and abortion-related mortality. We adopted this approach to determine the extent to which the respondents would spontaneously mention specific evidencebased interventions as methods for reducing the number of abortion-related deaths.

Interestingly, only four respondents spontaneously mentioned liberalization of the abortion law as a method to reduce the number of abortions, while nine mentioned liberalization as a method to reduce the number of abortion-related maternal deaths (Table 1). In contrast, the consensus among the policymakers was that sexuality education could reduce not only the number of abortions, but also the number of abortion-related maternal deaths. Indeed, 41 of the 49 respondents stated that sexuality education is important in dealing with the problem of abortion.* The following are examples:

"It should be the main prescription."-Health commissioner

"Constructive sexuality education is important." -Government health official

Other interventions mentioned in probed responses as ways to reduce the rates of abortion or abortion-related mortality were provision of effective family planning services, promotion of contraceptive use, empowerment of women, establishment of a functional health care system and provision of youth-friendly services.

Sexuality education was also the most commonly recommended intervention for promoting contraceptive use (not shown); it was cited in spontaneous responses as well as in probed questions about sexuality education. In addition, many respondents stated that inadequate and in-

* Respondents saw unwanted pregnancy and unsafe abortion primarily as a problem of young unmarried women, rather than of all women.
TABLE 1. Number of policymakers who spontaneously mentioned selected approaches to reducing abortion and abortion-related mortality in Nigeria, 2008

Approach

Abortion Abortionrelated mortality

Provide sexuality education

Encourage contraceptive use

Provide effective family planning services

Empower women

Liberalize the abortion law

Provide public health education and advocacy

Provide functional health system

Provide youth-friendly clinics

Promote abstinence

Educate the public about abortion

Establish antipoverty programs

Provide postabortion care training

35

16

0

0

9

9

7

3

0

0

0

4

Note: The 49 respondents were permitted to name as many approaches as they liked.

accurate information about contraception was responsible for low levels of method use. This situation can be corrected not only through sexuality education but also, as suggested by 20 of the respondents, by intense advocacy and public health education related to contraception. According to a government health official in Northwest Nigeria, "Advocacy and public health education by the health sector on family planning will correct the current negative religious and traditional dogmas that prevent the use of contraception."

In addition, 19 respondents recommended the delivery of effective family planning services as a means of increasing contraceptive use, while seven mentioned the reduction of costs of family planning services to ensure its accessibility and availability to all women.

\section{Ways to Reduce Maternal Mortality}

Finally, we asked respondents about ways to reduce maternal mortality in Nigeria. We asked this question to determine the extent to which the respondents would spontaneously mention the implementation of abortion-related interventions as approaches to reducing maternal mortal-

\section{TABLE 2. Number of policymakers who spontaneously mentioned selected approaches to reducing maternal mortality in Nigeria, 2008}

Approach

Provide functional health system

Provide effective health care delivery system

Offer free pregnancy care

Provide public health education/advocacy

Empower women

Increase women's access to health facilities

Liberalize the abortion law

Provide health insurance

Promote safe motherhood

Improve health policies

Train birth attendants to make earlier referrals

Promote involvement of NGOs

Provide free bed nets to pregnant women

No.

Note: The 49 respondents were permitted to name as many approaches as they

liked. NGOs=nongovernmental organizations. 
ity. Only three respondents spontaneously mentioned liberalization of the abortion law as a method to reduce maternal mortality (Table 2), apparently a reflection of the low priority accorded to abortion reform as a strategy for reducing maternal mortality and promoting safe motherhood. In contrast, there was general consensus of the need for health sector reform, as most respondents used phrases such as "functional health system" and "effective health care delivery system" to describe what they felt was needed to reduce maternal mortality. In addition, many participants mentioned "free medical services for pregnant women" and "public health advocacy" or "public health education" as approaches for reducing maternal mortality.

\section{DISCUSSION}

This study was designed to explore the attitudes and perceptions of key decision-makers in Nigeria regarding abortion and the country's abortion law. Although Nigeria has a federal system of government, the current law governing abortion is covered by the penal code in Nigeria's northern states and by the criminal code in the southern states. Within Nigeria's current legal and political system, a national law and related policies can be reviewed on a comprehensive basis at the national level only by the national assembly. However, opportunities for legal reform also exist at the state level, and a pronouncement in a case before the high court could provide an additional avenue for a legal amendment. The national scope of the existing law explains the focus of this study, wherein we targeted policymakers at the national level as well as decision makers in the country's six geopolitical zones. Indeed, the participants included many individuals who have the authority to make decisions on policies and legal frameworks addressing the problem of unsafe abortion in Nigeria.

To our surprise, we found that many participants had limited knowledge of the contribution of unsafe abortion to maternal mortality. Many provided narratives about women who had died or nearly died from unsafe abortion, but few could cite national statistics related to maternal deaths or abortion-related deaths. Moreover, although many acknowledged that maternal mortality is high in Nigeria and that unsafe abortion makes a significant contribution to maternal mortality, none specifically linked this information with the current abortion law or recognized the need to formulate policies and programs to address the problems. Moreover, abortion law reform was not seen as the best or most obvious way to reduce maternal mortality.

The results of these interviews indicate that abortion still has not been recognized as a problem requiring priority at the policy level, despite the large number of women who die every year from complications of unsafe abortion. For years, abortion has been a controversial issue in Nigeria, and several religious and antichoice organizations have taken strong positions against its practice. This situation may have conditioned policymakers not to address the issue.
Thus, it is essential to provide high-level policymakers with current information on abortion-related maternal mortality to increase their knowledge of the situation and to encourage them to develop relevant, scientifically appropriate solutions to the problem. Messages should focus on providing accurate statistics as well as graphic narratives of illustrative cases, and on explaining how the problem needs to be tackled, ideally using the experiences of other countries. For example, maternal mortality declined substantially in Romania after liberalization of the country's abortion law, ${ }^{20,21}$ and African countries such as South Africa and Ghana have also experienced significant improvements in their maternal health indicators following liberalization. ${ }^{22,23}$ In addition, policymakers should be made aware that none of these countries experienced increases in abortion following liberalization, and that the Netherlands, which has the most liberal abortion law in the world, also has the lowest rate of induced abortion.

Unfortunately, no formal forum exists for policymakers in Nigeria to discuss matters related to women's health. The Parliament of Ghana has a caucus that meets regularly to share information on reproductive health issues. ${ }^{24}$ This caucus has been responsible for promoting programs and policies (including the liberalization of abortion laws) designed to improve reproductive health in Ghana. Although the Nigerian National Assembly has standing committees on health and women's affairs, these committees have done little to address women's health needs. Indeed, the Health Committee of the Nigerian Senate has repeatedly blocked legislation on reproductive health, claiming that such legislation was a ploy to legalize abortion. ${ }^{25}$ Thus, an avenue for regularly sharing appropriate information with policymakers on maternal health, especially issues related to maternal mortality and unsafe abortion, is needed.

\section{Liberalization of the Abortion Law}

The abortion law in Nigeria stipulates that abortion is illegal unless it is needed to save the life of a woman. ${ }^{11}$ We found that although many policymakers knew that abortion is illegal in Nigeria, none could spontaneously recall specific provisions of the law. This situation may be attributable to the inadequate knowledge of maternal health among policymakers, and it provides further evidence that abortion is not a major subject of discourse among policymakers in Nigeria. Policymakers should be reminded repeatedly that the current law not only criminalizes women, but also drives the practice of abortion underground and makes it unsafe. Moreover, a recent review provided strong evidence that restrictive abortion laws do not reduce rates of abortion-related maternal mortality. ${ }^{26}$

Unfortunately, there are currently no initiatives by policymakers to review the law or to formulate specific policies to address the high rate of abortion-related maternal mortality in Nigeria. Opinions regarding the need to liberalize the abortion law in Nigeria varied. While many policymakers were against abortion reform, a significant num- 
ber supported liberalization, at least on health grounds. Arguments to influence policymakers' thinking on unsafe abortion may be more effective if they focus on the need for action to save women's lives and protect their health, in compliance with the provisions in the Nigerian constitution and other relevant statutes; the need to reduce the burden on the health system of treating complications due to unsafe abortion; and the fact that increasing access to safe abortion does not necessarily mean an increase in abortion.

The most common reasons cited by policymakers for nonsupport of abortion liberalization were religious and moral considerations. Although Nigeria is constitutionally a secular state, policymakers are increasingly influenced by religious factors, in large part because of the increasing militancy of religious bodies and antichoice organizations on abortion-related issues. ${ }^{27}$ Meanwhile, reproductive health advocates and prochoice organizations have made little effort to counter the antiabortion campaign. In such a situation, policymakers have little incentive or encouragement to address abortion as a public health issue; policymakers, being politicians and career officials, generally do not wish to jeopardize their careers, and therefore tend to align with the most vociferous public opinion on controversial issues. Thus, women's health advocates need to mobilize and encourage policymakers to take up abortion as a public health issue. Such advocacy efforts can be based on the principles of health for all (as enshrined in the Nigerian constitution), women's rights (as abortion affects only women), and basic human rights and social justice.

\section{Sexuality Education and Contraception}

While respondents were ambivalent about abortion liberalization, there was more support for family planning and sexuality education as approaches for reducing abortionrelated maternal mortality. In particular, policymakers viewed sexuality education as an important intervention that would not only increase contraceptive use but also reduce the number of unwanted pregnancies and unsafe abortions. The National Councils on Education and Health have approved a national curriculum for sexuality education in primary and secondary educational institutions in Nigeria, ${ }^{28}$ but a sizable number of states, especially the predominantly Muslim states in northern Nigeria, have failed to adopt the curriculum because of religious and moral considerations. Thus, the same religious institutions that oppose abortion also oppose family planning and sexuality education. Our findings that policymakers largely support both contraception and sexuality education is an important entry point for advocates seeking to promote these approaches for alleviating the problem of unsafe abortion.

Respondents believed that lack of awareness is a major reason that women do not use contraceptives to prevent unwanted pregnancies. Findings from the 2003 Nigeria Demographic and Health Survey challenge this assumption, since $77 \%$ of women aged $15-49$, and $91 \%$ of all sex- ually active unmarried women, knew a modern contraceptive method. ${ }^{14}$ However, the proportion of Nigerian women practicing contraception in 2003 was only 8\%, one of the lowest rates in Africa, and had not changed since 1999. ${ }^{29}$ In fact, the prevalence was higher in the 1980s than it is now, ${ }^{30}$ largely because of that decade's harsh economic climate, which forced many families to take birth control measures more seriously.

Although the policymakers we interviewed believed that the high cost of contraceptives is a deterrent to use, this is not borne out by the available evidence. In many parts of Nigeria, contraceptives are provided by funding agencies, nongovernmental organizations and government agencies either at no charge or at highly subsidized prices. However, contraceptives tend to be poorly distributed, especially in the rural communities where most women live, and this may act as a barrier to use. Additional factors that play a role in poor uptake of contraceptives in Nigeria include fear of side effects, the perception that contraceptives might cause infertility later in life and the notion among young people that obtaining an abortion is easier than using birth control. ${ }^{31,32}$ Addressing these issues may aid efforts to increase contraceptive uptake and reduce rates of unwanted pregnancies and unsafe abortion in Nigeria.

Finally, many policymakers cited improving the Nigerian health care system as essential for reducing maternal mortality, especially abortion-related maternal mortality, and suggested that an improved system would increase access to appropriate services, including family planning and postabortion care. A large proportion of policymakers supported the idea of free medical services for women, including postabortion care; this suggests that there is broad support for the recent decision by the federal government and some state governments in Nigeria to offer free medical services to pregnant women to improve maternal survival. ${ }^{33}$ Additionally, advocacy and public health education were strongly recommended by policymakers as approaches to increase awareness of the contribution of unsafe abortion to maternal mortality, and to mobilize resources and the political will to address related problems. The abysmally poor maternal health situation in the country, coupled with Nigeria's desire to attain the Millennium Development Goals (especially those related to the health of women and children), offer opportunities for women's health advocates to intensify their efforts to encourage governments and policymakers to address the problems of maternal mortality and unsafe abortion.

\section{Limitations and Conclusions}

A major limitation of this study is the noninvolvement of religious and traditional leaders, whose opinions likely influence policymakers' decisions. It is therefore essential to determine how religious and traditional leaders understand the problem of unsafe abortion within the context of Nigeria's high maternal mortality rate, and how their influence can be harnessed in addressing the problem. 
Another limitation of the study is the small number of women who participated. Interviewing more female policymakers would have allowed us to examine whether gender influences decisions on matters relating to induced abortion. However, relatively few female policymakers are in positions where they can make decisions on abortion. Future studies should explore women's views about induced abortion and abortion-related maternal mortality.

In conclusion, the results of this study suggest that policymakers are ambivalent about the need to liberalize the restrictive abortion law in Nigeria. However, they are likely to support sexuality education and increased access to contraceptives as approaches for reducing abortion-related maternal mortality; if better informed, they may increase their support for reforming the abortion law and for expanding the legal indications for abortion. Any progress made in reforming policies and activities relating to abortion and postabortion care in Nigeria will testify to the increasing official commitment to maternal health, and will reduce the inordinately high maternal mortality in the country.

\section{REFERENCES}

1. Ogiamien TE, Abortion law in Nigeria: the way forward, Occasional Seminar Papers, Benin City, Nigeria: Women's Health and Action Research Centre, 2000.

2. Henshaw SK et al., The incidence of induced abortion in Nigeria, International Family Planning Perspectives, 1998, 24(4):156-164.

3. Okonofua F, Preventing unsafe abortion in Nigeria, African Journal of Reproductive Health, 1997, 1(1):25-36.

4. Enhance Project, Reproductive Health in Nigeria: Situation, Response and Prospects, Abuja, Nigeria: Enhance and United States Agency for International Development, 2006.

5. Nigeria Federal Ministry of Health (FMOH), Abortion and Maternal Health in Nigeria, Abuja, Nigeria: FMOH, 1992

6. Raufu A, Unsafe abortions cause 20,000 deaths a year in Nigeria, BMJ, 2002, 325(7371):988.

7. Oye-Adeniran BA, Umoh AV and Nnatu SN, Complications of unsafe abortion: a case study and the need for abortion law reform in Nigeria, Reproductive Health Matters, 2002, 10(19):18-21.

8. Okonofua FE et al., Assessing the prevalence and determinants of unwanted pregnancy and induced abortion in Nigeria, Studies in Family Planning, 1999, 30(1):67-77.

9. Okonofua FE, Onwudiegwu U and Odutayo R, Pregnancy outcome after illegal induced abortion in Nigeria: a retrospective controlled historical study, African Journal of Medicine and Medical Sciences, 1994, 23(2):165-169.

10. Okonofua FE, Induced abortion: a risk factor for infertility in Nigerian women, Journal of Obstetrics and Gynaecology, 1994, 14(4): 272-276.

11. FMOH, National Reproductive Health Strategic Framework and Plan, 2002-2006, Abuja, Nigeria: FMOH, 2002.

12. Shiffman J and Okonofua FE, The state of political priority for safe motherhood in Nigeria, BJOG, 2007, 114(2):127-133.

13. FMOH, National Reproductive Health Policy and Strategy to Achieve Quality Reproductive and Sexual Health for All Nigerians, Abuja, Nigeria: FMOH, 2001.

14. Nigeria National Population Commission (NPC) and ORC Macro, Nigeria Demographic and Health Survey 2003, Calverton, MD, USA: NPC and ORC Macro, 2004.

15. World Health Organization (WHO), Twentieth World Health
Assembly resolution 20.14: health aspects of population dynamics, Geneva: WHO, 1967.

16. United Nations (UN), Report of the Fourth World Conference on Women, Beijing, 4-15 September 1995, New York: UN, 1996.

17. United Nations Population Fund (UNFPA), Key Actions for the Further Implementation of the Programme of Action of the International Conference on Population and Development, Adopted by the Twenty-First Special Session of the General Assembly, New York, 30 June-2 July 1999, New York: UNFPA, 1999.

18. Grimes DA et al., Unsafe abortion: the preventable pandemic, Lancet, 2006, 368(9550):1908-1919.

19. Oye-Adeniran BA, Long CM and Adewole IF, Advocacy for reform of the abortion law in Nigeria, Reproductive Health Matters, 2004, 12(24 Suppl.):209-217.

20. Hord C et al., Reproductive health in Romania: reversing the Ceausescu legacy, Studies in Family Planning, 1991, 22(4):231-240.

21. Stephenson P et al., Commentary: the public health consequences of restricted induced abortion-lessons from Romania, American Journal of Public Health, 1992, 82(10):1328-1331.

22. Stevens M, Abortion reform in South Africa, Initiatives in Reproductive Health Policy, 2000, 3(2):4-6.

23. Lithur NO, Destigmatising abortion: expanding community awareness of abortion as a reproductive health issue in Ghana, African Journal of Reproductive Health, 2004, 8(1):70-74.

24. Ghana Statistical Service (GSS) and Macro International, Ghana Demographic and Health Survey 1998, Calverton, MD, USA: GSS and Macro International, 1999.

25. A bill to establish a national institute of reproductive health, presented to the Senate of the Federal Republic of Nigeria by Sen. Daisy Danjuma, Oct. 15, 2005.

26. Okonofua FE, Contribution of anti-abortion laws to maternal mortality in developing countries, Expert Review of Obstetrics \& Gynecology, 2008, 3(2):147-149.

27. Mohammed I, Issues relating to abortions are complicated in Nigeria, BMJ, 2003, 326(7382):225.

28. Nigeria National Council on Education, National Sexuality Education Curriculum, Abuja, Nigeria: Federal Ministry of Education, 2004.

29. NPC, Nigeria Demographic and Health Survey 1999, Calverton, MD, USA: NPC and ORC Macro, 2000.

30. Ukoli FA and Oyarebu KA, An evaluation of contraceptive knowledge and practice in an urban community in Benin City in Nigeria, Indian Journal of Public Health, 1987, 31(1):33-39.

31. Okonofua FE et al., The social meaning of infertility in Southwest Nigeria, Health Transition Review, 1997, 7(2):205-220.

32. Otoide VO, Oronsaye F and Okonofua FE, Why Nigerian adolescents seek abortion rather than contraception: evidence from focusgroup discussions. International Family Planning Perspectives, 2001, 27(2):77-81.

33. Okonofua FE and Lambo E, Advocacy for free maternal and child health care in Nigeria: results and outcomes, unpublished manuscript.

\section{RESUMEN}

Contexto: En Nigeria, el aborto es permitido solamente para salvar la vida de la mujer. El aborto inseguro es común y es una causa importante de mortalidad materna; sin embargo, quienes formulan políticas han hecho poco para abordar el problema.

Métodos: En 2008, se condujo una serie de entrevistas a profundidad con 49 políticos y funcionarios nigerianos para evaluar su nivel de conocimiento respecto al aborto inseguro y su rol en la mortalidad materna; así como para determinar sus percepciones respecto a las políticas y acciones requeridas para dar respuesta a estos problemas. 
Resultados: Los participantes tenían un bajo conocimiento de la ley de aborto, o del número de abortos y de muertes relacionadas con ellos, aunque muchos se refirieron a mujeres que habían muerto o que estuvieron a punto de morir por causa de un aborto inseguro. Estas personas estaban guiadas por consideraciones morales y religiosas en vez de por enfoques actuales basados en la evidencia. Cerca de una tercera parte de los informantes consideró que el aborto no debería ser legal bajo ninguna circunstancia; una quinta parte apoyó la liberalización por "motivos médicos"; y una proporción similar consideró que el aborto debe ser legal en casos de violación e incesto. Las estrategias recomendadas por las personas entrevistadas para reducir la mortalidad materna incluyeron: facilitar el acceso a los anticonceptivos, brindar educación sexual, mejorar el sistema de salud, empoderar a las mujeres y proporcionar atención gratuita para el embarazo.

Conclusiones: Se necesita intensificar la educación en salud pública y el cabildeo dirigido a quienes formulan las políticas con el fin de aumentar la voluntad politica para reducir las muertes maternas relacionadas con el aborto en Nigeria. Es probable que la presentación de estadísticas sobre aborto inseguro, junto con historias personales convincentes, tengan resonancia en quienes formulan las políticas y contribuyan a un debate público informado sobre la reforma a la ley de aborto.

\section{RÉSUMÉ}

Contexte: Au Nigeria, l'IVG n'est autorisée que pour sauver la vie d'une femme. L'avortement non médicalisé est courant et constitue une cause majeure de mortalité maternelle. Les décideurs ne prêtent cependant guère attention au problème.

Méthodes: Des entretiens en profondeur ont été menés en 2008 avec 49 politiciens et responsables nigérians dans le but d'évaluer leur conscience de l'avortement non médicalisé et de son rôle dans la mortalité maternelle, ainsi que de déterminer leurs perceptions des politiques et mesures nécessaires à la résolution du problème.

Résultats: Les participants ne connaissaient guère la législation relative à l'avortement et n'étaient guère informés du nombre d'IVG pratiquées et de celui de décès liés à la procédure. Beaucoup ont cependant parlé de femmes mortes ou presque des suites d'un avortement non médicalisé. Les décideurs se sont révélés guidés par des considérations d'ordre moral et religieux plutôt que par les approches factuelles courantes. Environ un tiers des informateurs estime que l'IVG ne devrait être légale sous aucune circonstance; un cinquième en soutient la libéralisation pour «motifs médicaux» et une proportion comparable estime que l'IVG devrait être légale en cas de viol et d'inceste. Les stratégies recommandées par les répondants pour réduire la mortalité maternelle incluent la facilitation de l'accès à la contraception, l'éducation à la sexualité, l'amélioration du système de soins de santé, l'autonomisation des femmes et l'assurance de soins de grossesse gratuits.
Conclusions: Un effort intense de sensibilisation à la santé publique et de plaidoyer ciblé sur les décideurs est nécessaire si l'on veut accroître la volonté politique de réduire la mortalité liée à l'avortement au Nigeria. Les statistiques relatives à l'avortement non médicalisé et l'apport de témoignages personnels éloquents recevront vraisemblablement leur attention et contribueront à un débat public éclairé sur la réforme de la législation.

\section{APPENDIX:Interview guide}

1) You are probably aware that a large number of women die during pregnancy in Nigeria. In your opinion, what are the causes of these deaths?

- Probe for all medical causes of maternal death.

2) To what extent does abortion contribute to these deaths?

- Probe for cases of maternal death due to abortion that the respondent may be aware of.

3) What factors do you think are responsible for maternal deaths in Nigeria?

- Encourage respondent to list as many social, cultural, religious and other factors as possible.

4) What kinds of situations do you think make women resort to abortion in Nigeria?

- Probe further even if the respondent says abortion is illegal.

- Probe for as many reasons as possible, and if possible ask for examples of real cases.

5) In your opinion, how can the number of abortions be reduced in Nigeria?

6) Sexuality education for young people has been advocated as a method to reduce the need for abortion. What do you think about this?

7) What about contraception and family planning? Some women do not practice contraception, but rather resort to abortion. Why do you think this is the case? What do you think should be done?

8) What do you think about the abortion law in Nigeria? What kinds of changes, if any, do you think should be made?

- Probe for opinion in cases of incest, rape, danger to the health of the woman, etc.

9) What do you think the government and policymakers should do to reduce the number of maternal deaths in Nigeria?

- Probe for as many recommendations as possible.

10) What do you think the government and policymakers should do to reduce the number of abortion-related deaths?

- Probe for as many recommendations as possible.

\section{Acknowledgments}

The authors thank Chinwe Nwachukwu, Iyabo McOliver, Helen Obi, Joy Abara, Ivie Okonofua, Daisy Okonofua and Priscilla Idonuagbe for assistance in preparing the interview transcripts. They are grateful to John Onyeokoro for his assistance during the project, Ann Biddlecom for her advice and support, and Barbara Crane, Brooke Levandowski and officials at ESE:O for their helpful comments on the initial draft of this paper. Primary funding for the project was provided by Ipas; additional funding was provided by the UK Department for Internal Development on behalf of the Consortium on Research on Unsafe Abortion in Africa.

Author contact: feokonofua@yahoo.co.uk 